\title{
MANAGING HOUSEHOLD FINANCE: AN ASSESSMENT OF FINANCIAL KNOWLEDGE AND BEHAVIOUR OF RURAL HOUSEHOLDS
}

Krishna Murari*

\begin{abstract}
Managing household finance efficiently not only in urban areas but also among rural households has become the need of the hour in recent times. This study primarily aims at portraying the characteristics of rural households of Sikkim with reference to their level of financial knowledge and financial management practices. A sample of 98 rural households from the East and South districts of Sikkim was taken through a multistage sampling technique. Data were collected through schedule containing the question related to the financial knowledge and behaviour of the people. Financial knowledge of the rural people was assessed based on six dimensions, namely knowledge about credit management, ATM operations, interest on Savings account, insurance knowledge, unit pricing and inflation. The financial behaviour of the rural household was assessed based on eight practices such as budgeting practices, financial decision-making, household financial management, insurance products, financial activeness, cash management and retirement planning behaviour. The findings of the study conclude that the rural households possess a satisfactory financial knowledge score about ATM operations, insurance and unit pricing, but the knowledge about credit management, interest on savings account and inflation is really a serious concern and may be one of the leading factors to the poverty in rural households. Additionally, females were found to be more concerned and aware than males about the financial issues which indicates the financial empowerment among women of the State. In addition to this, among the ethnic groups, the Bhutia community scored highest in terms of financial knowledge scores followed by Nepali and Lepcha communities of rural households of Sikkim. The common financial practices such as preparing the household budget, managing the cash flow, planning for retirement or saving for contingencies are not in the habit of rural households to manage their finances. The scores of financial knowledge on the various dimensions are seen to be related to the financial management behavioural
\end{abstract}

*Associate Professor, Department of Management, Sikkim University, India.

Email:krishnamurari9@gmail.com

Journal of Rural Development, Vol. 38, No. 4, October - December : 2019 
practices. This means that the rural households having high knowledge scores in all the dimensions showed desirable and positive financial behaviours. This pattern indicates that if the financial knowledge of the rural households is increased over a period of time, their behaviours towards finance-related decision-making may be positive, and thus leading to an efficient household in terms of managing its finances.

Keywords: Household Financial Management, Financial Knowledge, Financial Behaviour, Rural Households, Sikkim.

\section{Introduction}

Managing household finance efficiently has become the need of the hour in recent times. It has gained a lot of attention from the government and the policymakers because the households are the main social units of savings in the country. Managing household finance in urban areas and that too by the financially literate people is not a much problem because they possess the necessary skills and ability to take financial decisions related to their personal finance. In India, majority of the population (approximately 70 per cent) lives in rural areas and they engage themselves in the agricultural and non-agricultural activities to make both ends meet. Besides this, the poverty, illiteracy, ill-health conditions and unemployment in these rural areas are just like devils which do not let the people grow in terms of prosperity. The only way to come out of such situations is to be financially literate and gain financial knowledge \& skills so that rural people can manage their funds effectively.

Being a student of finance, a few questions about rural people always make me tensed. Why rural people are still poor in
India despite so many supporting schemes being run by the government? Is it the lack of proper financial knowledge that makes them unable to manage their household finance? Are their financial decisions/outcomes/ choices/behaviour dependent on the financial knowledge they possess? What is the connection between financial knowledge and behaviour of rural households? What comprises household financial management? How people can manage their finances effectively? Do they require the necessary financial knowledge to manage their household funds? Does this level of literacy also account for the financial decision-making with reference to the financial knowledge and behaviour among rural households? These all are such questions which need answers. The connection between financial knowledge and behaviour is well explained and established with the urban population. But, whether such nexus also applies to the rural households of an ethnically and culturally diversified population within in a small State? This study tries to portray the characteristics of rural households of Sikkim with reference to the questions raised above. 


\section{Conceptual Background}

The concept of household is based on the arrangements made by persons, individually or in groups, for providing themselves with food or other essentials for living. A household may consist of one or more people who live in the same dwelling and share meals or living accommodation and may consist of a single family or some other grouping of people (Haviland, 2003). A single dwelling may be considered to contain multiple households if either meals or living space are not shared.

The income of the household is limited and hence, the members or the decisionmaker (Mukhiya or Karta of the household) must manage the finances to meet the daily needs and plan contingencies. The various financial management activities of the household can be in terms of making decisions ranging from very basic money management (tracking expenses, paying bills and dues on time) to more sophisticated ones (diversifying investments). The other finance-related decisions that a household may be involved in are arrangement of funds, risk minimisation, investment decisions, contingency planning and retirement planning. The list of activities in the household as mentioned above requires financial knowledge (of course because of financial education or literacy). There may be many more activities of its kind such as action taken in case of failure in the transaction with bank or ATM, ATM PIN hacking, cost and benefit analysis of any financial scheme, etc.

\section{Financial Literacy vis-à-vis Financial Knowledge}

Financial literacy can be referred to as the education and understanding of various financial areas. The financial education about personal finance-related aspects makes the persons financially literate which appropriate decisions about personal finance such as investing, insurance, real estate, paying for college, budgeting, retirement and tax planning.

The Organisation for Economic Cooperation and Development (OECD) has defined financial literacy as "a combination of awareness, knowledge, skill, attitude and behaviour necessary to make sound financial decisions and ultimately achieve individual wellbeing."In previous studies on financial literacy, researchers have used different dimensions of financial literacy. Few researchers have used financial literacy and financial knowledge interchangeably (Huston, 2010) and others have only considered financial knowledge and took it as synonymous to financial literacy (Robb \& Woodyard, 2011).

\section{Financial Behaviour}

Xiao (2008) defines financial behaviour as any human behaviour that is relevant to money management. The common financial behaviour includes the practices related to cash, credit, savings and investments. Consumer Economists have been studying financial behaviour for the last four decades across the globe. Fitzsimmons et al. (1993) did 
a study on financial behaviour from the 1970s to early 1990s. The efforts continued over the years and recently in the last decade, there have been more studies on financial behaviour (Hogarth, Hilgert, and Schuchardt, 2002; Hilgert, Hogarth \& Beverly, 2003; O'Neill \& Xiao, 2003; Xiao, 2006\& 2008).

To make the readers clear about the concepts, the term financial knowledge is used to refer the skills and ability to take personal finance-related decisions. This ability to take finance-related decisions is expected to induce the financial choice or outcome (behaviour) of the people.

In order to make people financially knowledgeable and capable of taking their household finance-related decisions and effective use of money, the financial education programmes organised by government and other financial institutions and agencies should focus not only on financial knowledge and financial awareness but also on the assessment of financial attitude and financial behaviour too (Delafrooz \& Paim 2011; Bhushan \& Medury, 2014).

\section{Statement of the Problem}

To develop a comprehensive understanding of rural villagers' ability to manage money, their interaction with the formal financial system, and the relationship between these activities and their behaviour, rural households' financial knowledge is to be assessed in this study. Financial knowledge encompasses the necessary ability and skills for taking a decision regarding a range of money-related activities and includes planning and prioritising short and long-term spending, savings, investment, the management of credit, the management of cash flows and budgeting, and the management and enhancement of income generation. This study primarily aims at assessing the financial knowledge and financial behaviour of rural households of people of Sikkim and its connection with household financial management.

\section{Review of Literature}

Since economic reforms in 1991, financial education has been given importance in India by the government agencies and policymakers. Initially, the pace of emphasis was slow, but gradually it gained momentum over the years. This increased interest in financial education has been prompted by the increasing complexity of financial products and the increasing responsibility on the part of individuals for their own financial security. Well-informed and financially educated consumers are better able to make good decisions for their families and thus are in a position to increase their economic security and well-being (Hilgert, Hogarth, \& Beverly, 2003). Thus, financial education is important not only to individual households and families but to their communities as well. Amongst the growing concerns about consumers' financial literacy, the financial education programmes focus on providing information to consumers 
and operate under the implicit assumption that increases in financial knowledge will lead to changes in financial management practices and behaviours. The following subsections bring out the contributions of the various researchers in exploring the linkage between financial knowledge and behaviour of individuals and households.

\section{Financial Knowledge and Behaviour}

In developed countries, many studies have been carried out to explore the connection between financial knowledge and behaviour of the people. A positive connection has been found between financial knowledge and behaviour of household respondents (Asaad, 2015; Hilgert et al., 2003; Alhenawi \& Elkhal, 2013). Hilgert et al. (2003) reported 18 households' financial management practices ranging from very basic money management skills (tracking expenses and paying bills on time) to more sophisticated ones (diversifying investments). The financial practices were categorised as cash-flow management, credit management, saving, investment, and others. The numeracy as one of the variables of financial knowledge does not lead to improved behaviour towards retirement planning (Gustman, Steinmeier, \& Tabatabai, 2012). The saving in the rural household is affected by the income, physical wealth, household size and years of schooling (Amimo et al., 2004) and by the contextual factors such as proximity to the bank and the presence of informal savings mechanisms (Chowa, Ansong,
\& Despard, 2014). Besides, the lack of access to formal financial intermediaries pushes rural households to use their own grassroots associations for many services.

The college and school-going students have also been the centre of studies (Borden, Lee, Serido \& Collins, 2008; Mandell \& Klein, 2009; Xiao, Ahn, Serido \& Shim, 2014) to evaluate the impact of financial education seminar (Borden et al., 2008) or personal financial management course (Mandell \& Klein, 2009) towards the financial responsibility exhibited in their financial behaviours. Not only the students but also the farmers showed better financial knowledge and improved savings and borrowings behaviours on account of financial literacy training programme (Sayinzoga, Bulte, \& Lensink, 2016). A complex nature of the relationship between personal financial knowledge and credit card behaviour of students was also observed by Robb \& Sharpe (2009). Contrary to the expectations, those with higher levels of financial knowledge had significantly higher credit card balances, thus showing a poor financial management approach.

\section{Psychological Traits as the Driver to Financial Behaviour}

Financial knowledge is an important but insufficient driver of responsible financial behaviour. In addition to the financial knowledge, the psychological traits such as self-esteem Tang \& Baker (2016); social and economic geography (Stenning et al., 2010); 
mental budgeting (Antonides, Groot, \& Raaij, 2011); locus of control (Perry \& Morris, 2005) were also found to be significant in explaining the financial behaviour and thereby overall household financial management practices. The studies suggest that there exist a positive relationship (although weak, sometimes) between financial knowledge and behaviour of people, but the direction of the causality is unknown (Hilgert et al., 2003; Allgood \& Walstad, 2016).

\section{Role of Demographics}

The role of demographic variables cannot be ignored in examining the household financial choices and the determinants of financial services in rural and urban households (Akpandjar, Quartey \& Abor, 2013; Robb \& Woodyard, 2011; Krah, Aveh \& Addo, 2014). The demographic variables that have a significant role in determining the financial behaviour include household size, age, sex, marital status, occupation, income, ethnicity, race, remittances and shocks. However, in the study of Loke (2015), age and ethnicity did not significantly affect financial wellness. The results also suggest that when the alternatives to financial services are available, rural households are more likely than urban households to obtain their financial services from the informal financial sector. Findings suggested that community characteristics affect rural households' financial capability.

Although many studies have been carried out to explore the relationship of financial knowledge and behaviour of individuals and households (both rural and urban) in developed and developing countries, the studies from rural households of India are scanty. The determinants and patterns of savings and financial practices differ from rural to urban region in India (Nayak, 2013; Kumar \& Mukhopadhyay, 2013; Agarwalla et al., 2015. In rural areas, the farmers' cognitive ability being assessed using education and financial experience, can explain the financial aptitude and debt literacy, i.e., the financial literacy (Gaurav \& Singh, 2012). Besides this, demographic variables such as age, education, income, occupation, etc., are also key determinants of saving and investment behaviour of rural households (Maheshwari, 2016). In the Indian context, the need of financial education programme, seminars, discussions has been emphasised upon (Bhushan \& Medury, 2014; Hira, 2012) to increase the financial knowledge of rural households and thereby its expected impact on the improved financial behaviours that will ultimately lead to sound management of household finances.

\section{Rationale of the Study}

The dearth of studies from rural households of India explaining the connection between financial knowledge and behaviour and that too asymmetric are the important reasons to carry out this study. Additionally, the literature as reviewed in the previous section about the relationship between the ability to 
manage money and the impact this has on financial behaviour is fragmented and thus has motivated me to focus on disadvantaged rural households of Sikkim in highly urbanised environments. The rural population being the major representative of the people of Sikkim, very less information is available about levels of financial knowledge and patterns of financial behaviour in rural communities.

\section{Objectives of the Study}

Keeping the background mentioned above in mind, the study is carried out to achieve the following objectives:

$\checkmark \quad$ To study the demographic and ethnic differences in financial knowledge and financial behaviour among people of Sikkim.

$\checkmark \quad$ To study the levels of financial knowledge among rural households of Sikkim.

$\checkmark$ To describe the behaviour of rural households towards various areas of financial decision-making related to household finance.

$\checkmark \quad$ To explore the relationship between the financial knowledge and behaviour of rural households.

\section{Data \& Methodology}

The blueprint for the collection, measurement and analysis of data has been prepared keeping in mind the various dynamics of the rural population of the Sikkim. For this study, a descriptive research design method has been used, wherein the financial knowledge and behaviour of the rural households have been described by asking certain standardised questions in the form of a schedule.

\section{Sampling Design}

The population for the sampling of the households was all the rural households of the State of Sikkim. Further, a disproportionate multi (three) stage area sampling method is used to select the sample at three levels, i.e. at district, sub-division and village level. A sample size of 98 households (statistically calculated sample size $=96$ based on 95 per cent confidence level and 10 per cent margin of error) is spread disproportionately (as a percentage of the rural population of each district and sub-division) at each stage of sampling. The structural representation of the sampling design is presented in Figure 1. The villages and number of households for the survey were selected based on the judgemental criteria as mentioned in the research design of the study. The criterion for selection was the accessible road connectivity to the villages and households.

\section{Research Instrument}

Data were collected through primary source by designing a schedule addressing the questions related to the financial knowledge and behaviour of the people. The schedule was prepared by customising the internationally accepted and standardised questionnaire for 


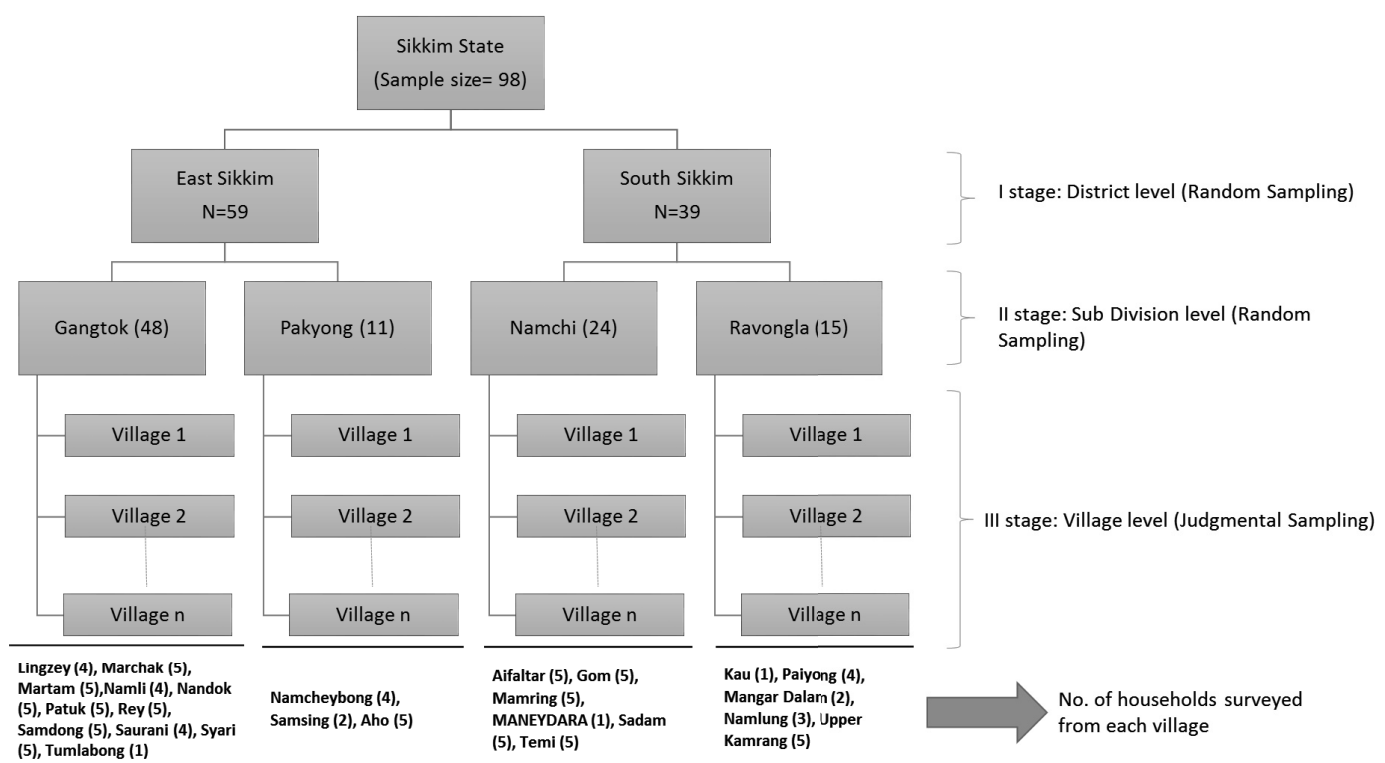

Figure 1: Sampling Approach

measuring the financial literacy developed by OECD INFE (2011). Some items in the schedules were also taken from the financial literacy assessment quiz developed by the Government of Canada (2017) and customised in the Indian context. In the beginning, the schedule comprised of demographic information of the people such as gender, ethnicity, age, marital status, children, etc. Financial knowledge of the rural people was assessed based on their knowledge about credit management (3 questions), ATM operations (4) and interest on Savings account (4), insurance knowledge (1), unit pricing (1), inflation (1) and overall financial knowledge. The financial behaviour of the rural household was assessed based on budgeting (2), financial decision-making (3), household financial management (4), insurance product (1), financial activeness (3), cash management (2) and retirement planning (3). The data collection through schedule was done during a period of five months, i.e., from March to July 2017.

\section{Tools for Analysis}

Data collected in the above-stated manner were entered and processed using statistical software. A descriptive analysis including cross tabulation, percentage, graphs, etc., for the various dimensions of financial knowledge and financial behaviour was generated using SPSS \& MS Excel.

\section{Analysis of Data \\ Population Dynamics in Sikkim}

The North-East Region of the country is given a special treatment in terms of its balanced growth and development. Among 
the eight North-Eastern States, Sikkim is widely known for its tourism and pharmaceutical industries. The people of Sikkim constitute mainly of four ethnic groups- Nepali, Lepcha, Bhutia and Sherpa. The Lepchas are the original inhabitants of the State. Compared to other ethnic groups, the Lepchas still maintain many of their traditional customs. The Bhutias comprise the Bhutia from Sikkim and Bhutia from Bhutan and Tibet. The Sherpas are a marginal ethnic group in the State. Over 70 per cent of the population consists of Nepalese. They are a dominant ethnic group in the State. According to the 2011 census, the total population of Sikkim stands at 610,577 which is the accumulation of 43,709 (7.16 per cent) belonging to North district, 136,435 (22.34 per cent) belonging to the West district, 146,850 (24.05 per cent) belonging to the South district and 283,583 (46.45 per cent) belonging to the East district. Out of this total population, 74.85 per cent lives in rural areas while 25.15 per cent lives in urban areas (Census of India: Sikkim, 2011). With most of the rural population in the State, out of total households, 82.4 per cent accounts for rural households in Sikkim. In South district, 85.56 per cent population lives in rural areas while the remaining 14.44 per cent lives in the urban areas. Similarly, in the case of the East district, 56.81 per cent population lives in rural area while 43.19 per cent in the urban areas. Besides this, the State claims to have one of the highest literates (literacy rate of 81.4 per cent) (Govt. of Sikkim, 2013).

\section{Demographic Profile of the Respondents}

Using the stated sampling methodology, approximately 60 per cent and 40 per cent of the households were surveyed from east and south districts of Sikkim, respectively. The demographic profile of the sample is shown in Table 1. The studies (Krah, Aveh \& Addo, 2014) have reported that demographic profiles (gender, income levels, age of household, etc.) have a significant relationship with the levels of financial knowledge and household financial management practices such as budgeting and level of saving.

Gender-wise distribution of the responding members from the households shows that males (62.24 per cent) participated more in comparison to females (37.76 per cent). Majority of the people under the survey were married (78.6 per cent), whereas 19.4 per cent of respondents were single.

Ethnicity-wise, 78.6 per cent people in the rural households of Sikkim represented the Nepali ethnic group followed by Bhutia and Lepcha both at 9.2 per cent. However, the Sherpa ethnic group could not be surveyed because of the poor access to their households in the respective villages. Only 3.1 per cent of the rural people were found to be in another category, i.e., Muslims.

The average age of the respondents was 39 years (Table 1). However, the minimum and maximum age of the respondents was found to be 21 and 70 years, respectively. Maximum 
(39.8 per cent) respondents were the age group of 30-40 years followed by young people (2130 years) with 22.4 per cent.

\section{Financial Decision-Making in Day-to-Day Matters}

Usually, the financial decision-making in day-to-day matters is performed by the Mukhiya of the family and it is also evident from the Table 2. 42.9 per cent of the people in the sample claim that they are solely responsible for decision-making in all financial matters. However, 23.5 per cent of people take financial decisions in consultation with their partner. 14.3 per cent claims that the financial decision-making is done by their partner and other family members in the household.

Among ethnic groups, Nepali and Bhutia communities follow the same pattern, but in Lepcha community, the Mukhiya and the partner together (66.7 per cent) prefer making financial decisions related to day-to-day affairs.

Table 1: Demographic Profile of the Respondents

\begin{tabular}{|c|c|c|c|}
\hline \multicolumn{2}{|c|}{ Demographic Profile of Respondents } & \multirow{2}{*}{\begin{tabular}{|r} 
Count \\
61
\end{tabular}} & \multirow{2}{*}{\begin{tabular}{|c|} 
Percentage (\%) \\
$62.2 \%$
\end{tabular}} \\
\hline Gondor & Male & & \\
\hline 与errue? & Female & 37 & $37.8 \%$ \\
\hline \multirow{4}{*}{ Marital Status } & Married & 77 & $78.6 \%$ \\
\hline & Single & 19 & $19.4 \%$ \\
\hline & Separated/ Divorced & 1 & $1.0 \%$ \\
\hline & widowed & 1 & $1.0 \%$ \\
\hline \multirow{4}{*}{ Ethnicity } & Nepali & 77 & $78.6 \%$ \\
\hline & Bhutia & 9 & $9.2 \%$ \\
\hline & Lepcha & 9 & $9.2 \%$ \\
\hline & Others & 3 & $3.1 \%$ \\
\hline \multirow{7}{*}{ Age Profile } & $21-30$ years & 22 & $22.4 \%$ \\
\hline & $30-40$ years & 39 & $39.8 \%$ \\
\hline & $40-50$ years & 20 & $20.4 \%$ \\
\hline & More than 50 years & 17 & $17.3 \%$ \\
\hline & Minimum Age & \multicolumn{2}{|r|}{21 years } \\
\hline & Maximum Age & \multicolumn{2}{|r|}{70 years } \\
\hline & Mean Age & \multicolumn{2}{|r|}{39 years } \\
\hline
\end{tabular}

Source: Sample Survey Data. 
Table 2: Ethnicity-wise Decision Making in Day-t0-Day Matters

\begin{tabular}{|c|c|c|c|c|c|c|}
\hline $\begin{array}{c}\text { Who is responsible } \\
\text { for decision making } \\
\text { in day-to-day } \\
\text { matters? }\end{array}$ & Statistics & Nepali & Bhutia & Lepcha & Others & Total \\
\hline You & $\mathrm{N}$ & 37 & 2 & 1 & 2 & 42 \\
\cline { 2 - 8 } & $\mathrm{N} \%$ & $48.10 \%$ & $22.20 \%$ & $11.10 \%$ & $66.70 \%$ & $42.90 \%$ \\
\hline $\begin{array}{c}\text { You and your } \\
\text { partner }\end{array}$ & $\mathrm{N}$ & 15 & 2 & 6 & 0 & 23 \\
\cline { 2 - 8 } & $\mathrm{N} \%$ & $19.50 \%$ & $22.20 \%$ & $66.70 \%$ & $0.00 \%$ & $23.50 \%$ \\
\hline $\begin{array}{c}\text { You and another } \\
\text { family member }\end{array}$ & $\mathrm{N}$ & 4 & 1 & 0 & 0 & 5 \\
\cline { 2 - 8 } & $\mathrm{N} \%$ & $5.20 \%$ & $11.10 \%$ & $0.00 \%$ & $0.00 \%$ & $5.10 \%$ \\
\hline \multirow{2}{*}{\begin{tabular}{c} 
Your partner \\
\cline { 2 - 7 }
\end{tabular}} & $\mathrm{N} \%$ & 11 & 2 & 1 & 0 & 14 \\
\hline Another family & $\mathrm{N}$ & 10 & 2 & 1 & 1 & 14 \\
\cline { 2 - 7 } member & $\mathrm{N} \%$ & $13.00 \%$ & $22.20 \%$ & $11.10 \%$ & $33.30 \%$ & $14.30 \%$ \\
\hline
\end{tabular}

\section{Financial Knowledge Score Construction}

Financial knowledge implies that rural households can make a rational choice among different financial alternatives based on their inclusive knowledge of everyday financial matters. The level of financial knowledge of the rural households was assessed using a series of 14 basic questions which aimed at testing their knowledge related to basic concepts and operational aspects of day-to-day finance. These questions included the aspects such as credit management, ATM operations, interest on savings accounts, insurance awareness, unit pricing and inflation. The questions were simple and did not require any tricky calculations, and we expect that the rural households possess a moderate or high level of financial knowledge as the State claims to be 78.9 per cent of literacy rate in the rural sector (Sikkim, 2013). The financial knowledge aspects of the respondents are mapped on a scale of 0 to 3 (3.16 to be exact), according to their weighted responses to the questions. The correct answer for each question is given a score of one and then the total score was later converted into percentage. The categorisation of different financial knowledge scores and levels is explained in Table 3.

Table 4 depicts the methodology for construction of the weighted scores to assess the financial knowledge of the households. Based upon the number of questions asked in each dimension of financial knowledge, 
Table 3: Distribution of Score for Financial Knowledge

\begin{tabular}{|l|l|}
\hline Weighted Score of Financial Knowledge & Level of Financial Knowledge \\
\hline Less than 1 & Low \\
\hline 1 to 2 & Moderate or Average \\
\hline More than 2 & High \\
\hline
\end{tabular}

Table 4: Weighted Average Score Construction

\begin{tabular}{|l|c|c|c|}
\hline *FK dimension & $\begin{array}{c}\text { No. of } \\
\text { questions }\end{array}$ & Weight & $\begin{array}{c}\text { Maximum } \\
\text { weighted score }\end{array}$ \\
\hline Credit Management & 3 & 0.21 & 0.64 \\
\hline ATM operations & 4 & 0.29 & 1.16 \\
\hline Interest on Savings & 4 & 0.29 & 1.16 \\
\hline Insurance & 1 & 0.07 & 0.07 \\
\hline Unit Pricing & 1 & 0.07 & 0.07 \\
\hline Inflation & 1 & 0.07 & 0.07 \\
\hline Total & 14 & 1 & 3.16 \\
\hline *FK: Financial knowledge & & & \\
\hline
\end{tabular}

the proportionate weight was assigned. Later, a maximum weighted score was obtained by multiplying the number of questions in each dimension of financial knowledge with their respective weights.

\section{Assessment of Financial Knowledge}

The performance on different dimensions of financial knowledge is shown in Figure 2 which suggests inadequate financial knowledge in terms of credit management, interest on savings accounts and inflation. Sadly, 60 per cent of the households were not even able to understand the concepts of credit management and 52 per cent were even unaware of the basic knowledge about the interest on savings accounts (see Figure 2). Further, the knowledge about ATM operations and insurance is also a matter of concern since 31 per cent and 32 per cent, respectively, could not answer the questions under these dimensions. Even on the questions related to inflation, 38 per cent of the respondents could not give the correct answer. These findings are in line with (Dara, 2014) who stated that one-third of the households in three districts of Andhra Pradesh are still marginalised with 
limited or no access to basic financial services, including microfinance and insurance. This is again a matter of concern for policymakers as the rural households are poor with respect to the basic financial knowledge. Jayanthi \& Rau (2017) also found that a low level of financial knowledge will contribute to poor financial decisions and that can be harmful to both individuals and society.

The financial knowledge score between males and females do not vary much in the category of high score although the females (51.35 per cent) scored more than the males (47.54 per cent) in moderate category of financial knowledge score (Figure 3). However, males were more in the lowest score category than females. These findings have also been endorsed by Semmler (2016) stating that females are more knowledgeable and responsible towards financial matters.

The young people in rural households were expected to possess the high score on the scale of financial knowledge, but it was revealed that only 31.8 per cent could make it in age group of 21-30 years and 50 per cent and 18.2 per cent scored as moderate and low scores, respectively, in the same age group (Table 5). This is again a grave concern and needs serious attention because this age group is the future of the household. A similar trend was also observed in the age group of 4050 years where 60 per cent scored moderate followed by only 35 per cent in high score of financial knowledge. However, a satisfactory percentage of people (48.7 per cent) and 43.6 per cent was seen in high and moderate scale, respectively.

Across the ethnic groups of the households, Bhutia household managed to possess high score (55.6 per cent) of financial knowledge in comparison to Nepali (41.6 per cent) and Lepcha (11.1 per cent) communities. However, majority of the Lepcha households were in moderate category of financial knowledge score followed by Nepali (49.4 per cent) and Bhutia (33.3 per cent) in the same category. However, among Lepcha households, 33.3 per cent being in the low category of financial knowledge score, is a matter of concern (Figure 4).

Based upon the self-assessment about financial knowledge, the respondents were asked to rate themselves. The results show that among those who considered themselves knowledgeable, only 50 per cent could make it into the high score category followed by 43 per cent in moderate score (Figure 5). This shows the over-confidence of the rural households related to the financial knowledge they possess. Further, 79 per cent of households rated themselves as not very knowledgeable and their scores were also in low to moderate category. This again adds to a little worrisome situation of rural households in terms of their perception about the financial knowledge they should have, to deal with their household financial management. 


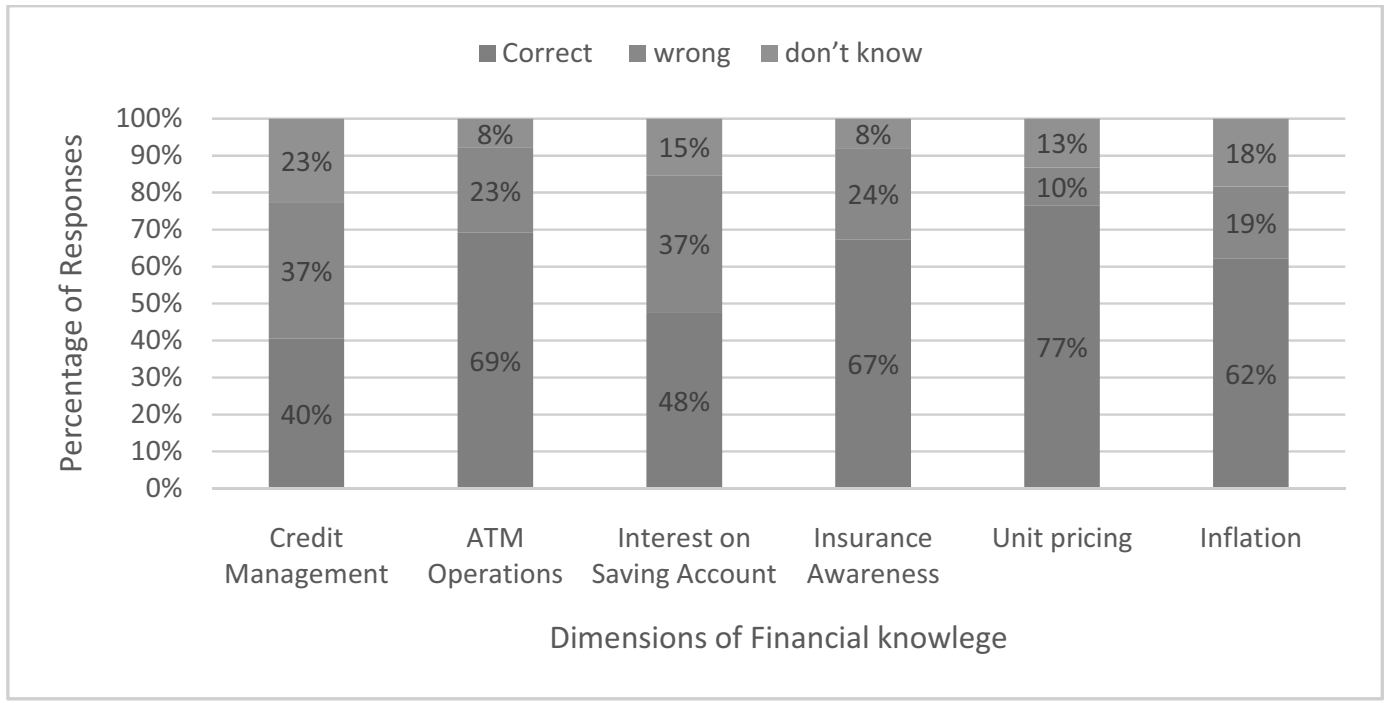

Figure 2: Assessment on Dimensions of Financial Knowledge

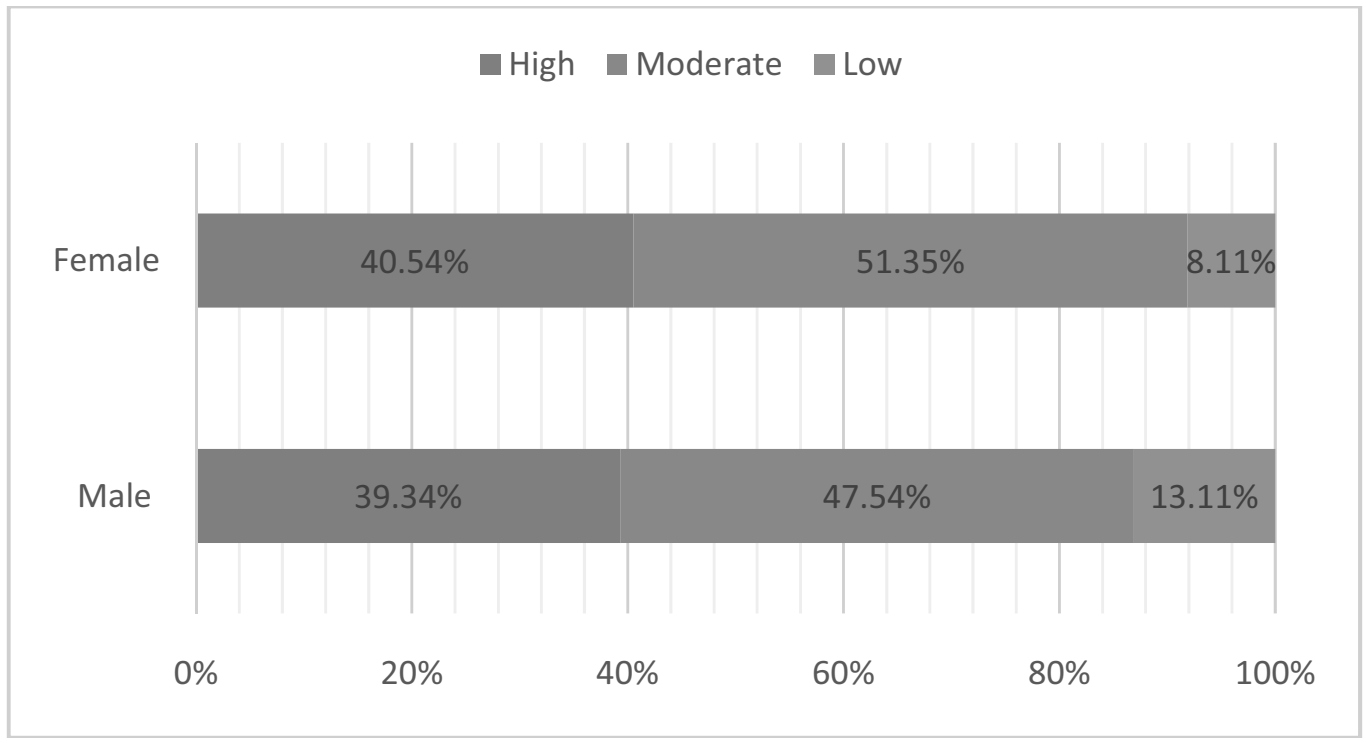

Figure 3: Gender-wise Score of Financial Knowledge 


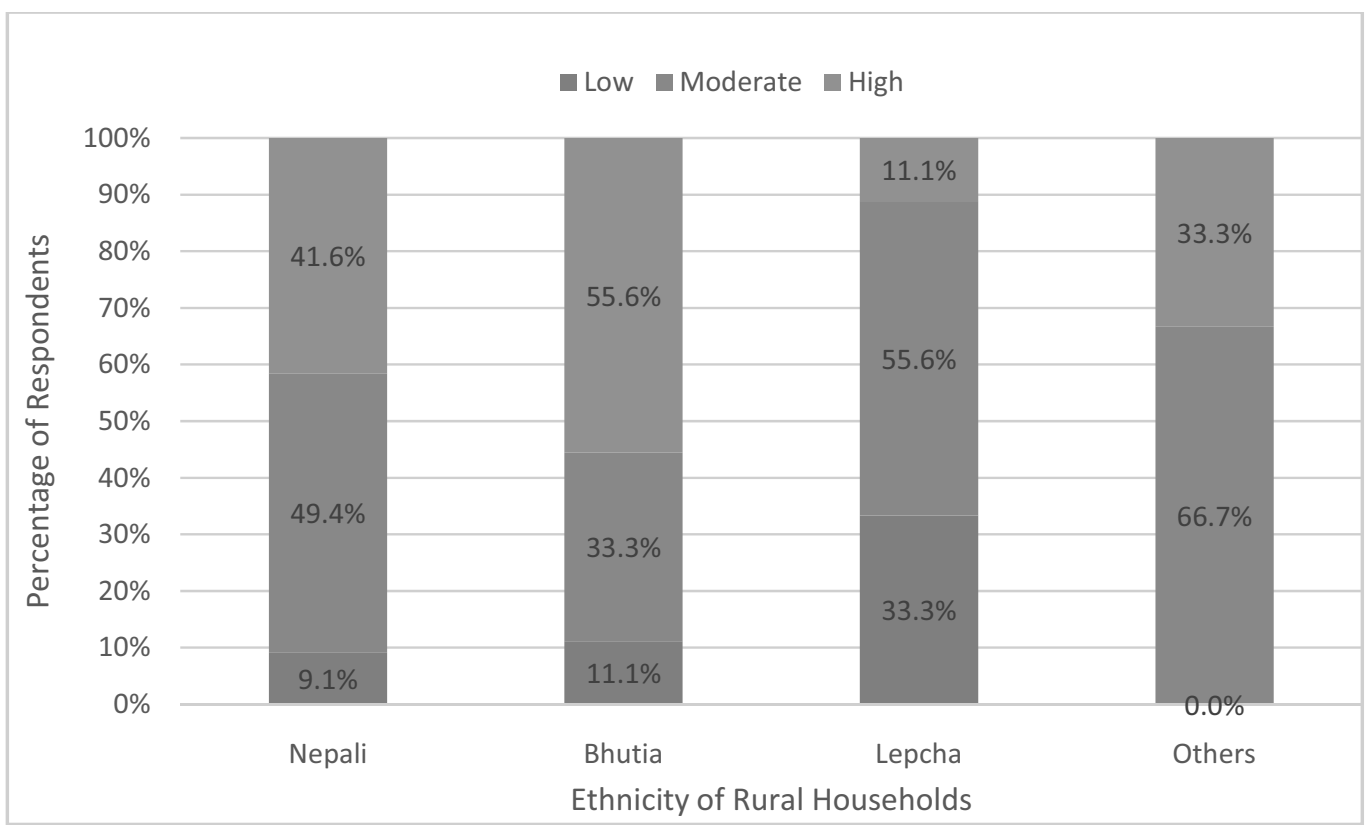

Figure 4: Ethnic Groups and Financial Knowledge

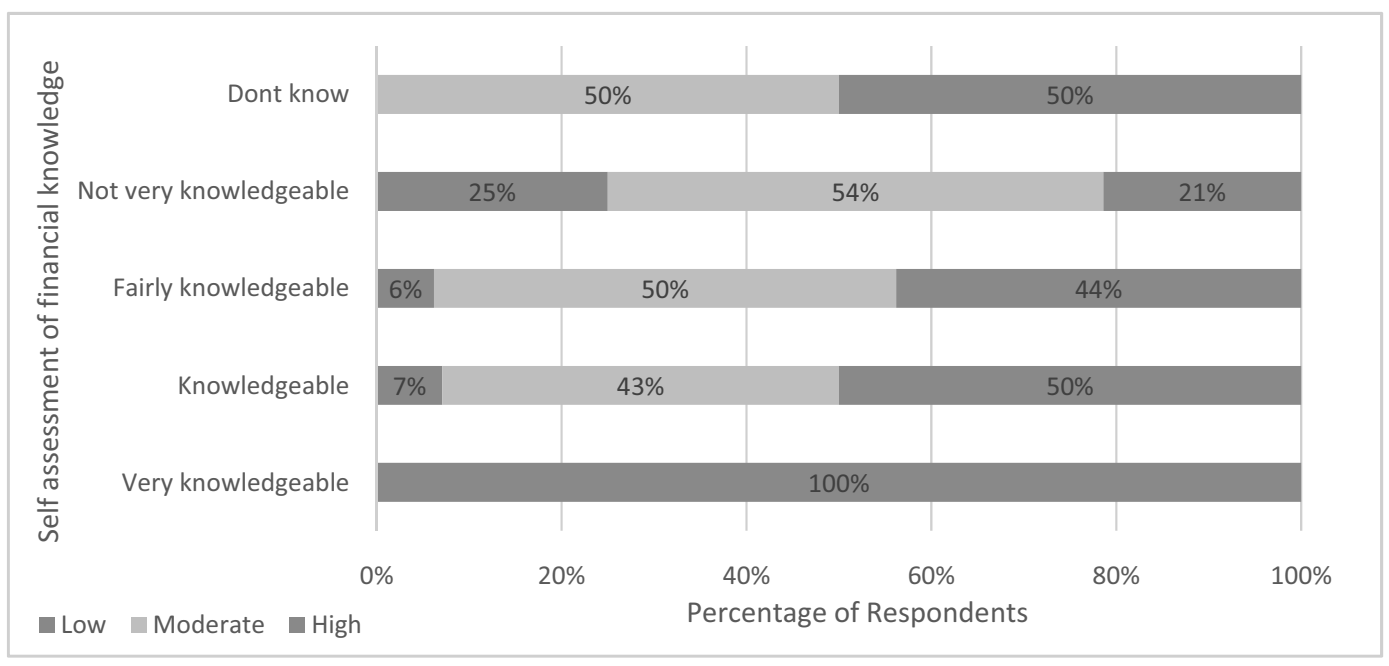

Figure 5: Self-assessment of Financial Knowledge 
Table 5: Age-wise Financial Knowledge Scores

\begin{tabular}{|l|c|c|c|c|c|c|}
\hline \multirow{2}{*}{ Age categories } & \multicolumn{6}{|c|}{ Financial Knowledge Score } \\
\cline { 2 - 7 } & \multicolumn{2}{|c|}{ Low } & \multicolumn{2}{c|}{ Moderate } & \multicolumn{2}{c|}{ High } \\
\cline { 2 - 7 } & Count & Row N \% & Count & Row N \% & Count & Row N \% \\
\hline 21-30 years & 4 & $18.2 \%$ & 11 & $50.0 \%$ & 7 & $31.8 \%$ \\
\hline 30-40 years & 3 & $7.7 \%$ & 17 & $43.6 \%$ & 19 & $48.7 \%$ \\
\hline 40-50 years & 1 & $5.0 \%$ & 12 & $60.0 \%$ & 7 & $35.0 \%$ \\
\hline More than 50 years & 3 & $17.6 \%$ & 8 & $47.1 \%$ & 6 & $35.3 \%$ \\
\hline
\end{tabular}

Source: Author's Calculations.

To sum up, it is observed that the knowledge about credit management, interest on savings account and inflation-related dimensions are really serious concerns and can lead to poor financial decision-making and adding to the poverty among rural households of Sikkim. However, females were found to be more concerned and aware than males about the financial issues in line with the findings of Arora (2016) which indicate the financial empowerment among women of the State. Most rural people in the age groups of 21-30 years and $40-50$ years possess a moderate level of financial knowledge and need to be given attention by the policymakers. In addition to this, the Bhutia community scored highest in terms of financial knowledge followed by Nepali and Lepcha communities among the ethnic groups of rural households of Sikkim.

\section{Sources of Financial Knowledge}

It is evident from the Table 6 that the preferred source of financial knowledge among rural households of Sikkim is the information from the business and financial programme on radio and television (68.8 per cent of the respondents) followed by the 65.6 per cent of the respondents getting financial knowledge from newspapers. Due to the increase in reachability of smartphones and cheaper access to the internet, 42.7 per cent people also prefer to be updated about financial knowledge through the internet. A substantial percentage of people come to know about the various financial aspects related to their day-to-day operations, from their children and financial advisors figuring at 28.1 per cent and 20.8 per cent, respectively. Financial magazines, current event magazines and other sources (such as people, friends and family) are least preferred sources of financial knowledge among rural households of Sikkim (Table 6).

\section{Assessment of Financial Behaviour}

The study also attempted to capture 
Table 6: Source of Financial Knowledge among Rural Households

\begin{tabular}{|c|c|c|c|}
\hline \multirow{2}{*}{ Source of Financial Knowledge ${ }^{a}$} & \multicolumn{2}{|c|}{ Responses } & \multirow{2}{*}{ Per cent of Cases } \\
\hline & $\mathbf{N}$ & Per cent & \\
\hline Newspapers & 63 & $25.5 \%$ & $65.6 \%$ \\
\hline Financial/Business section of the newspaper & 7 & $2.8 \%$ & $7.3 \%$ \\
\hline Financial magazines & 5 & $2.0 \%$ & $5.2 \%$ \\
\hline Current event magazines & 3 & $1.2 \%$ & $3.1 \%$ \\
\hline Information given by children & 27 & $10.9 \%$ & $28.1 \%$ \\
\hline Business \& financial programmes on radio \& TV & 66 & $26.7 \%$ & $68.8 \%$ \\
\hline Internet & 41 & $16.6 \%$ & $42.7 \%$ \\
\hline Financial Advisor & 20 & $8.1 \%$ & $20.8 \%$ \\
\hline Any other (people, friends \& family members) & 4 & $1.6 \%$ & $4.2 \%$ \\
\hline Don't Know & 11 & $4.5 \%$ & $11.5 \%$ \\
\hline Total & 247 & $100.0 \%$ & $257.3 \%$ \\
\hline
\end{tabular}

aDichotomy group tabulated at value 1 .

Source: Author's Calculations.

the financial behaviour of rural households, particularly the ways they handle their personal finances. For this purpose, the people in the selected rural households were asked 18 questions in total to understand the important dimensions about how these people behave while handling money in their daily lives. These dimensions included the questions which were asked in the OECD survey. The financial behaviour of the rural household was assessed based on Budgeting (2 questions), Financial Decision Making (3 questions), Household Financial Management (4 questions), Risk Management (1 question), Financial Activeness (3 questions), Bill payment (1question), Cash Management (1 question) and Retirement Planning (3 questions).
Financial knowledge does seem to influence specific financial management behaviours (Bell, Gorin \& Hogarth, 2009). Hence, to identify the financial management behaviours, the responses related to the household budgeting, bill payment and retirement planning were re-coded as desirable or undesirable behaviour as shown in Table 7 . Only 35 per cent of the rural households of Sikkim prepare the budget of their income and expenses. However, most of the rural households (76 per cent) have not failed in paying their due bills in the last 12 months.

In addition to this, as expected, due to poor financial knowledge in managing the household finance, 70 per cent of the rural households do not bother about their 
Table 7: Desirable Behaviour of Rural Households to the Dimensions of Financial

Behaviour

\begin{tabular}{|l|c|c|}
\hline \multicolumn{1}{|c|}{ Dimension of financial behaviour } & $\begin{array}{c}\text { Desirable } \\
\text { behaviour }\end{array}$ & $\begin{array}{c}\text { Percentage of } \\
\text { responses }\end{array}$ \\
\hline $\begin{array}{l}\text { Household Budgeting (Do you prepare a budget of income } \\
\text { and expenses for your household?) }\end{array}$ & Yes & 35 \\
\hline $\begin{array}{l}\text { Bill Payment (In the last 12 months, were you ever behind two } \\
\text { or more consecutive months in paying your rent, bills, loan or } \\
\text { mortgage?) }\end{array}$ & No & 76 \\
\hline $\begin{array}{l}\text { Retirement Planning (Do you have a good idea of how } \\
\text { much money you will need to save to maintain your desired } \\
\text { standard of living when you cross 60 years?) }\end{array}$ & Yes & 30 \\
\hline
\end{tabular}

Source: Author's Calculations.

retirement planning and only 30 per cent care and think about the money they would need to live the desired standard of living after they cross 60 years (Figure 6).

Further, among those who prepare the household budget, only 20 per cent showed positive financial behaviour, i.e., staying within the budget either 'always' or 'usually' (Table 8). This is a serious concern which again needs the attention of the policymakers with respect to the financial behaviour of the rural households in Sikkim. However, out of those 76 per cent who claimed that they did not have any problem in paying the bills in last 12 months, only 52 per cent could show the positive behaviour towards cash management, i.e., 'keeping up with the payments without any problem.

The financial decision-making (FDM) behaviour and household financial management (HFM) behaviour were re-coded as positive, negative and neutral behaviour for the items included in both the dimensions based upon the expected behaviour according to the level of financial knowledge. Basically, rural households are expected to be 'agree' for showing positive behaviour, 'disagree' for negative behaviour and 'don't know' for neutral behaviour with respect to FDM dimension of financial behaviour. Similarly, a financially knowledgeable or knowledgeable household is expected to show the positive behaviour if they rate themselves in 'very good' or 'good' category; the negative behaviour with 'fairly good' or 'not very good' category and neutral behaviour with 'don't know'.

Among rural households, 86 per cent expressed their positive behaviour towards financial decision-making (FDM) and household financial management (HFM). However, 52 per cent and 53 per cent in FDM and HFM, respectively, showed a negative behaviour of the rural households (Figure 7).

As expected, the awareness in rural households about the risk management 


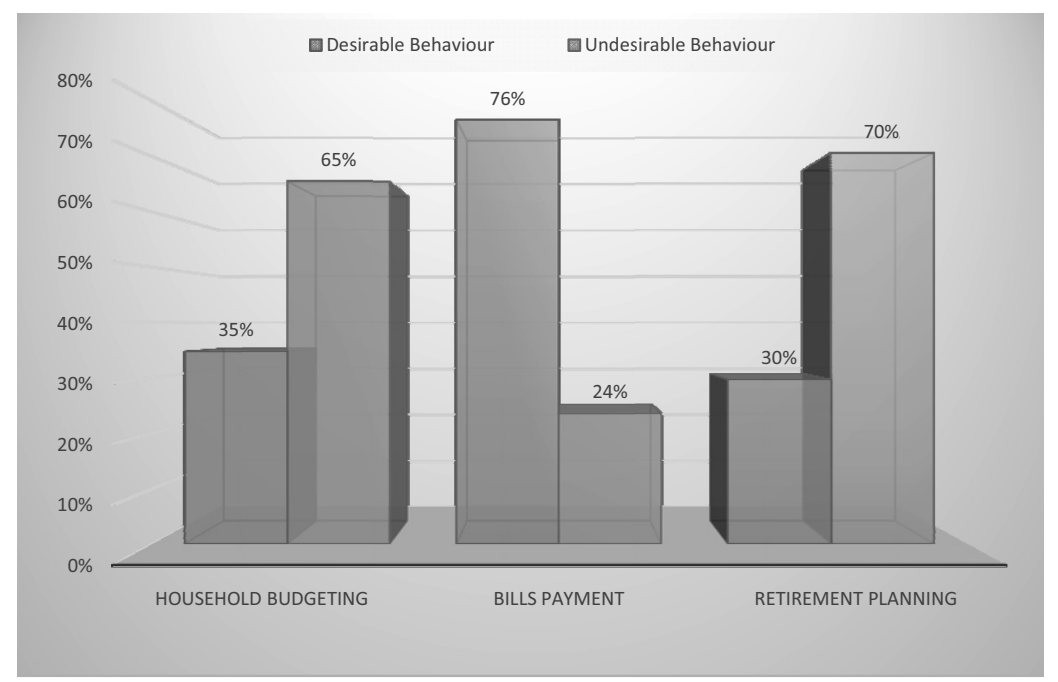

Figure 6: Pattern of Financial Behaviour among Rural Households in Sikkim

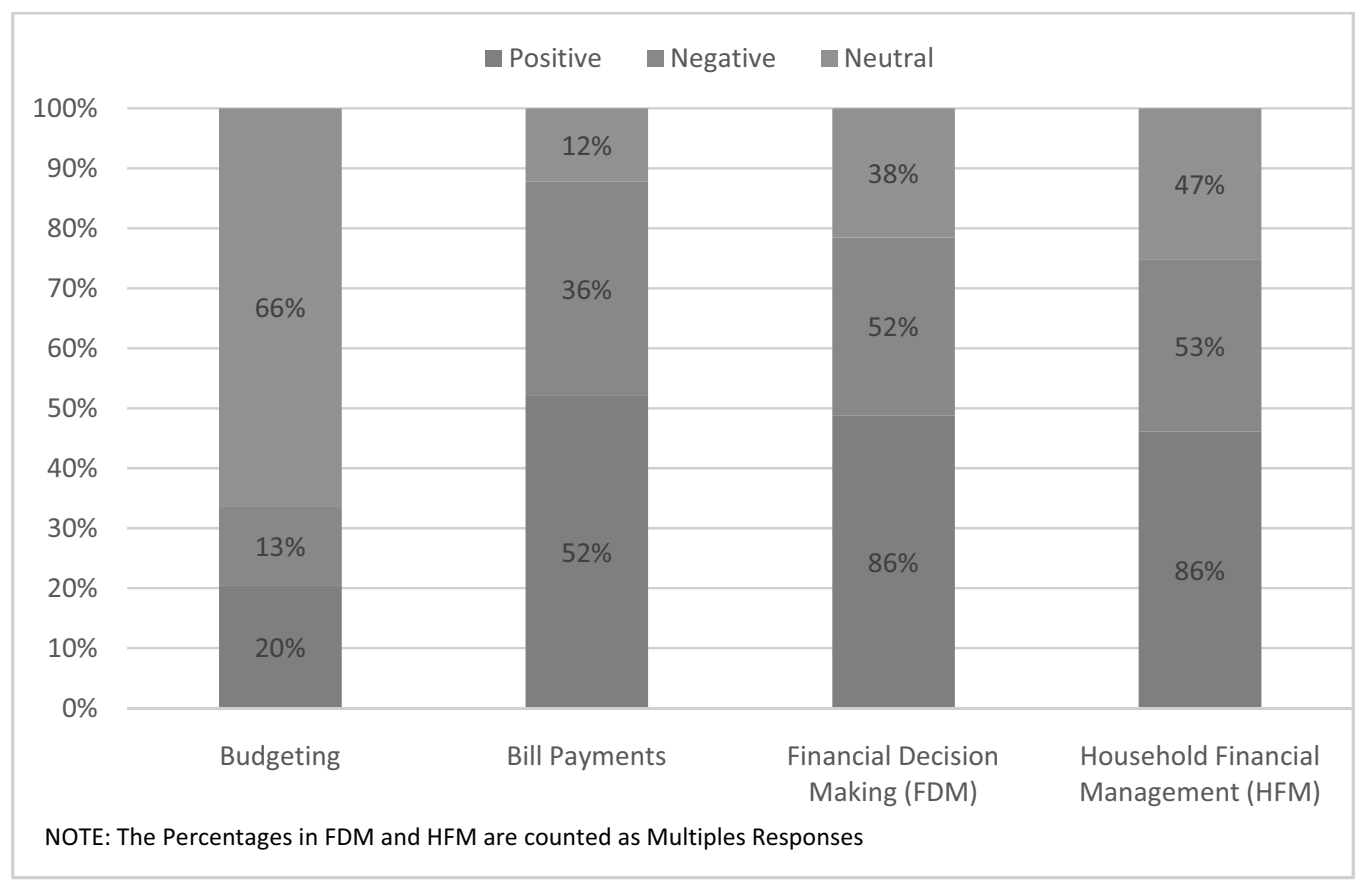

Figure 7: Levels of Financial Behaviour 
Table 8: Financial Behaviour across Various Dimensions

\begin{tabular}{|c|c|c|}
\hline Dimension of Financial Behaviour & Positive Behaviour & $\begin{array}{l}\text { Percentage } \\
\text { of cases }\end{array}$ \\
\hline Budgeting (How often do you stay within your budget?) & Always or Usually & 20 \\
\hline $\begin{array}{l}\text { Cash Management (How have you been keeping up with } \\
\text { payment of bills and other commitments during the last } 12 \\
\text { months) }\end{array}$ & $\begin{array}{l}\text { Keeping up without } \\
\text { any problem }\end{array}$ & 52 \\
\hline $\begin{array}{l}\text { Financial Decision Making (FDM) } \\
\text { I have a clear idea of the financial products that I need } \\
\text { I know enough about investments to choose those that } \\
\text { are suitable to my circumstances } \\
\text { I always research my choices thoroughly before making } \\
\text { any financial decisions }\end{array}$ & $\begin{array}{l}\text { Agree } \\
\text { Agree } \\
\text { Agree }\end{array}$ & $86^{*}$ \\
\hline $\begin{array}{l}\text { Household Financial Management (HFM) } \\
\text { Keeping track of money } \\
\text { Making ends meet } \\
\text { Shopping to get the best financial products such as } \\
\text { loans or insurance } \\
\text { Staying informed about financial issues }\end{array}$ & $\begin{array}{l}\text { Very good or Good } \\
\text { Very good or Good } \\
\text { Very good or Good } \\
\text { Very good or Good }\end{array}$ & $86^{*}$ \\
\hline
\end{tabular}

*taken as percentage count of multiple responses

Source: Author's Calculations.

instruments is poor. Approximately, 47 per cent of rural households do not use any risk management instrument. However, life insurance is used by 46 per cent of the rural respondents. This can be treated as a signal of relief against uncertainties to the life of the key person in rural families. Yet, the other risk management instruments such as auto insurance, medical insurance, property insurance, travel insurance, etc., are not used by rural people (Table 9 ).

Whether the rural people keep themselves financially active? To answer this, they were asked to respond to the financial areas which they personally keep an eye with respect to the changes in that area. The results in Table 10 show that inflation (by 57.7 per cent) and consumer goods \& services (by 43.3 per cent) are the preferred areas among rural households for keeping themselves financially active.

The changes in the housing sector and taxation (this is surprising because there is no personal income tax on the income of people of Sikkim origin) are being monitored by 28.9 per cent of the respondents followed by interest rates and pension plans and other retirement benefits by 21.6 per cent and 20.6 per cent, respectively. However, the rural households showed least interest in the stock market, 
Table 9: Risk Management Behaviour of Rural Households

\begin{tabular}{|l|c|c|c|}
\hline \multirow{2}{*}{ Risk Management Instrument Used } & \multicolumn{2}{|c|}{ Responses* } & \multirow{2}{*}{ Percentage of Cases } \\
\cline { 2 - 3 } & $\mathbf{N}$ & Per cent & \\
\hline Auto Insurance & 10 & $8.5 \%$ & $10.2 \%$ \\
\hline Life Insurance & 45 & $38.5 \%$ & $45.9 \%$ \\
\hline Disability/ Medical Insurance & 11 & $9.4 \%$ & $11.2 \%$ \\
\hline Property Insurance & 4 & $3.4 \%$ & $4.1 \%$ \\
\hline Travel Insurance & 1 & $0.9 \%$ & $1.0 \%$ \\
\hline None of the Above & 46 & $39.3 \%$ & $46.9 \%$ \\
\hline Total & 117 & $100.0 \%$ & $119.4 \%$ \\
\hline
\end{tabular}

*responses are counted as Dichotomy from multiples responses.

Source: Author's Calculations.

currency market and any other area such as land, gold prices and insurance market. 22.7 per cent of the rural people also showed their inactiveness towards the changes in any of the listed areas. This shows the lack of awareness among rural people about the formal components of the financial system.

As far as the means of future contingency planning is concerned, 48.4 per cent of rural people rely upon the income from farming and self-employment activities for meeting both the ends during their life post 60 years of age while 32.6 per cent believes that the government pension will be a financial support during their tough time (Table 11). This shows the lack of retirement planning skills among rural households and it can be directly attributed to the poor levels of financial knowledge. Other preferred modes for sustaining life post 60 years of age are relying upon the financial support from the extended family members (by 27.4 per cent), earnings from employment during retirement (by 27.4 per cent) and through maturity of personal savings plans made for retirement benefit (by 25.3 per cent). Selling of financial and nonfinancial assets and inherited property for meeting the expenses are also seen as a mode of livelihood as a way of retirement planning in rural households. In addition to this, around 14 per cent of the households are even not aware of any source of income for their retirement.

\section{Factors Influencing Financial Behaviour}

Based upon the sources of financial knowledge as shown in Table 6, the factors actually influencing their financial decisionmaking (behaviour) is shown in Table 12. The financial and business programmes on radio or television play a significant role in influencing the financial behaviour of rural people (69.8 per cent). 
Table 11: Financial Behaviour towards Retirement Planning

\begin{tabular}{|c|c|c|c|}
\hline \multirow{2}{*}{$\begin{array}{l}\text { Retirement Planning } \\
\text { (Sources of income considered for retirement) }\end{array}$} & \multicolumn{2}{|c|}{ Responses* } & \multirow{2}{*}{$\begin{array}{l}\text { Per cent of } \\
\text { Cases }\end{array}$} \\
\hline & $\mathbf{N}$ & Per cent & \\
\hline $\begin{array}{l}\text { Government pension benefits (old age pension } \\
\text { scheme, etc.) }\end{array}$ & 31 & $14.00 \%$ & $32.60 \%$ \\
\hline $\begin{array}{l}\text { Occupational or working place pension plan } \\
\text { benefits }\end{array}$ & 10 & $4.50 \%$ & $10.50 \%$ \\
\hline $\begin{array}{l}\text { Personal retirement savings plan benefit (by the } \\
\text { maturity of investment made in pension plans) }\end{array}$ & 24 & $10.90 \%$ & $25.30 \%$ \\
\hline $\begin{array}{l}\text { Sell your financial assets (such as stocks, bonds, } \\
\text { mutual funds) }\end{array}$ & 7 & $3.20 \%$ & $7.40 \%$ \\
\hline $\begin{array}{l}\text { Sell your non-financial assets (such as car, home, } \\
\text { jewellery, etc.) }\end{array}$ & 12 & $5.40 \%$ & $12.60 \%$ \\
\hline Use an inheritance & 8 & $3.60 \%$ & $8.40 \%$ \\
\hline Rely on financial support from your extended family & 26 & $11.80 \%$ & $27.40 \%$ \\
\hline $\begin{array}{l}\text { Drawing an income from your own (or spouse or } \\
\text { partner's) business }\end{array}$ & 15 & $6.80 \%$ & $15.80 \%$ \\
\hline Earnings from employment in retirement & 26 & $11.80 \%$ & $27.40 \%$ \\
\hline $\begin{array}{l}\text { Income from Farming and self-employment } \\
\text { activities }\end{array}$ & 46 & $20.80 \%$ & $48.40 \%$ \\
\hline Others (friends \& family support) & 3 & $1.40 \%$ & $3.20 \%$ \\
\hline Don't know & 13 & $5.90 \%$ & $13.70 \%$ \\
\hline Total & 221 & $100.00 \%$ & $232.60 \%$ \\
\hline
\end{tabular}

*counted as Dichotomy group from multiples responses tabulated at value 1.

Source: Author's Calculations

The second most powerful financial behaviour influencing factor is advice from a knowledgeable friend or family member (45.8 per cent) and is followed by newspapers (36.5 per cent) at third place. Surprisingly, the rural households consider the advice from financial advisor as a source of financial updating (knowledge), but the words of advice of the financial advisor are not preferred as a key factor to influence the financial decision- making behaviour (Krah, Aveh \& Addo, 2014) of rural people in Sikkim (Table 12).

\section{Conclusion}

The entire study is focused on the finding out the status of financial knowledge and behaviour of the rural households of the Sikkim and explaining the role of these two (knowledge and behaviour) in managing the household finances. The sample in this study 
Table 12 : Factors Influencing the Financial Behaviour of Rural Households

\begin{tabular}{|l|c|c|c|}
\hline \multirow{2}{*}{ What influences the financial behaviour?a } & \multicolumn{2}{|c|}{ Responses } & \multirow{2}{*}{ Percentage of Cases } \\
\cline { 2 - 3 } & $\mathbf{N}$ & Per cent & \\
\hline Advertisements & 29 & $12.1 \%$ & $30.2 \%$ \\
\hline Magazines & 8 & $3.3 \%$ & $8.3 \%$ \\
\hline Newspapers & 35 & $14.6 \%$ & $36.5 \%$ \\
\hline Radio or TV & 67 & $27.9 \%$ & $69.8 \%$ \\
\hline Internet & 34 & $14.2 \%$ & $35.4 \%$ \\
\hline Advice from financial advisor & 10 & $4.2 \%$ & $10.4 \%$ \\
\hline $\begin{array}{l}\text { Advice from a knowledgeable friend or fam- } \\
\text { ily member }\end{array}$ & 44 & $18.3 \%$ & $45.8 \%$ \\
\hline None of the above & 2 & $0.8 \%$ & $2.1 \%$ \\
\hline Don't know & 11 & $4.6 \%$ & $11.5 \%$ \\
\hline Total & 240 & $100.0 \%$ & $250.0 \%$ \\
\hline
\end{tabular}

aDichotomy group tabulated at value 1 .

Source: Author's Calculations.

comprises the rural households from the selected districts of the Sikkim State of India. In contrast to the results of the similar studies in urban areas, it was expected that the rural households will have the poor knowledge about the financial issues that are required to be dealt with while managing the day to day finance. As per the expectations, the rural households had poor knowledge about credit management, interest on savings account and inflation concepts. However, the financial knowledge about ATM operations, insurance and the concept of unit pricing was satisfactory. The programmes on radio and television, newspapers and the internet are the preferred sources of acquiring knowledge related to financial aspects.
The common financial practices such as preparing the household budget, managing the cash flow, planning for retirement or saving for contingencies are not in the habit of rural households to manage their finances. This is really a challenge to the policymakers that even in the $21^{\text {st }}$ century the rural households are deprived of such basic financial planning tools and techniques. If this is the case, how can we think of a poverty-free India?

\section{Policy Implications}

The findings of the study can be of great concern to the policymakers in the areas of rural development. The financial knowledge among rural people can be improved with the necessary steps and measures by government 
or even by the private sector by conducting financial knowledge enhancing workshops, campaigns, role plays (explaining through enacting a financial concept and its use in daily life), etc. (Bhargava, 2016; Bhattacharya \& Dutta, 2016; Xu \& Zia, 2012) Till date, the focus of such programmes had been in the urban areas only, but they can be extended to villages as well. These financial literacy programmes should be specifically designed by understanding the needs of rural people. The content of such programmes can be any topic which can help the uplifting of rural households such as savings and expenditure management, need of insurance and retirement planning, credit and debt management, investment avenues, risk management, formal financial system and effective financial decision-making.

Initiatives can also be taken to provide financial education at the grassroots level, i.e., to the kids at the school level or at least in the colleges (Bell, Gorin \& Hogarth, 2009). This may help in inculcating the financial knowledge and attitude among students so that they can implement the learnings in managing their household finances efficiently and effectively during their adulthood.
Further, it is also important that rural households exploit such financial knowledge in their financial behaviour as an outcome of the gained knowledge for wealth accumulation (Krah, Aveh \& Addo, 2014). The State policymakers may think of asking the branches of banks or financial institutions in rural areas to adopt at least one village for ensuring the enrichment of financial knowledge of its habitants. The government can sponsor such programmes or provide incentives to such villages that help in promoting financial literacy in the State and country, thereby boosting the economic development.

Lastly, there can be many other factors like education of family, quality of education and self-confidence of the rural people which influences the financial knowledge and behaviour of the households and these can be considered in future studies. There is a need to examine the financial literacy programmes leading to improved knowledge, behaviour and attitude of the rural households at the country level. It is possible that the results may differ if the same survey is conducted in States having large population and geographical areas. 


\section{References}

Agarwalla, S. K., Barua, S. K., Jacob, J., \&Varma, J. R. (2015), Financial Literacy among Working Young in Urban India, World Development, 67, 101-109. https://doi.org/10.1016/j.worlddev.2014.10.004.

Akpandjar, G. M., Quartey, P., \& Abor, J. (2013), Demand for financial services by households in Ghana, International Journal of Social Economics, 40(5), 439-457. https://doi. org/10.1108/03068291311315322.

Alhenawi, Y., \& Elkhal, K. (2013), Financial Literacy of U.S. Households: Knowledge vs. Long-term Financial Planning, Financial Services Review, 22, 211.

Allgood, S., \& Walstad, W. B. (2016), The Effects of Perceived and Actual Financial Literacy on Financial Behaviours, Economic Inquiry, https://doi.org/10.1111/ecin.12255.

Amimo, O., Larson, D. W., Bittencourt, M., \& Graham, D. H. (2004), The Potential for Financial Savings in Rural Mozambican Households, Savings and Development, 28(2), 157-178.

Antonides, G., Groot, I. M. de, \& Raaij, W. F. van. (2011), Mental Budgeting and the Management of Household Finance, Journal of Economic Psychology, 32(4), 546-555, https://doi.org/10.1016/j. joep.2011.04.001.

Arora, A. (2016), Assessment of Financial Literacy among working Indian Women, Business Analyst, 36(March), 219-237.

Asaad, C. T. (2015), Financial Literacy and Financial Behaviour: Assessing Knowledge and Confidence, Financial Services Review, 24, 101-117.

Bell, C. J., Gorin, D. R., \& Hogarth, J. M. (2009), Does Financial Education Affect Soldiers' Financial Behavior? Retrieved 6 16, 2018, from https://papers.ssrn.com/sol3/papers.cfm?abstract_ $\mathrm{id}=1445635$.

Bhargava, N. R. (2016), A Study on Financial Literacy and Financial Education: An Overview of Scenario in India, Research Journal of Management Sciences, 5(9), 51-57.

Bhattacharya, M., \&Dutta, P. (2016), Financial Inclusion and its Delivery Models in India-Select Issues, Global Journal for Research Analysis, 5(6), Retrieved 6 16, 2018, from http://worldwidejournals.in/ ojs/index.php/gjra/article/view/8212/8280.

Bhushan, P., \& Medury, Y. (2014), An Empirical Analysis of Inter Linkages between Financial Attitudes, Financial Behaviour and Financial Knowledge of Salaried Individuals, Indian Journal of Commerce \& Management Studies, V(3), 58-65. 
Borden, L. M., Lee, S. A., Serido, J., \& Collins, D. (2008), Changing College Students' Financial Knowledge, Attitudes and Behaviour through Seminar Participation, Journal of Family and Economic Issues, 29(1), 23-40. https://doi.org/10.1007/s10834-007-9087-2.

Census of India: Sikkim. (2011), District Census Handbook: North, West, South and East Districts Village and Town-wise Primary Census Abstract (PCA), Directorate of Census Operations: Sikkim.

Chowa, G., Ansong, D., \& Despard, M. R. (2014), Financial Capabilities: Multilevel Modeling of the Impact of Internal and External Capabilities of Rural Households, Social Work Research, https://doi. org/10.1093/swr/svu002.

Dara, N. R. (2014), Current Status of Financial Inclusion Among Rural Households in A.P., Retrieved 6 15, 2018 from https://morebooks.de/store/gb/book/current-status-of-financial-inclsuionamong-rural-households-in-a-p/isbn/978-3-8484-8845-2.

Delafrooz, N., \& Paim, L. H. (2011), Determinants of Saving Behaviour and Financial Problem among Employees in Malaysia, Australian Journal of Basic and Applied Sciences.

Gaurav, S., \& Singh, A. (2012), An Inquiry into the Financial Literacy and Cognitive Ability of Farmers: Evidence from Rural India, Oxford Development Studies, 40(3), 358-380. https://doi.org/1 $0.1080 / 13600818.2012 .703319$.

Government of Canada. (2017), Financial Literacy Self-assessment Quiz, Retrieved August 19, 2017, from https://itools-ioutils.fcac-acfc.gc.ca/FLSAT-OAELF/star-comm-eng.aspx.

Gustman, A. L., Steinmeier, T. L., \& Tabatabai, N. (2012), Financial Knowledge and Financial Literacy at the Household Level, The American Economic Review, 102(3), 309-313.

Hilgert, M. A., Hogarth, J. M., \& Beverly, S. G. (2003), Household Financial Management: The Connection between Knowledge and Behaviour, Federal Reserve Bulletin, 106(July), 309-322.

Hira, T. K. (2012), Promoting Sustainable Financial Behaviour: Implications for Education and Research, International Journal of Consumer Studies, 36(5), 502-507, https://doi.org/10.1111/ j.1470-6431.2012.01115.x.

Huston, S. J. (2010), Measuring Financial Literacy, Journal of Consumer Affairs, https://doi. org/10.1111/j.1745-6606.2010.01170.x. 
Jayanthi, M., \& Rau, S. (2017), An Empirical Study on Financial Literacy and Spending Behaviour of Rural Household in India, Asian Journal of Management, 8(4), 1115-1119. Retrieved 615,2018 from http://ajmjournal.com/abstractview.aspx?pid=2017-8-4-26.

Krah, R. Y., Aveh, F. K., \& Addo, R. (2014), An Exploratory Study of Financial Management Practices Among Ghanaian Households, International Journal of Management and Sustainability, 3(7), 393414, Retrieved 6 16, 2018, from https://ideas.repec.org/a/pkp/ijomas/2014p393-414.html.

Kumar, L., \& Mukhopadhyay, J. (2013), Patterns of Financial Behaviour Among Rural and Urban Clients: Some Evidence from Tamil Nadu, India. IMTFI Working Paper 2013-9.

Loke, Y. J. (2015), Determinants of Financial Behaviours among Malaysians, The Journal of Applied Economic Research, 2(2), 121-132. https://doi.org/10.5897/AJBM10.1267.

Maheshwari, T. (2016), Saving and Investment Behaviour of Rural Household (With Special Reference to Coimbatore District), International Journal of Multidisciplinary Research and Development Online Issue, 3(3), 2349-4182.

Mandell, L., \& Klein, L. S. (2009), The Impact of Financial Literacy Education on Subsequent Financial Behaviour, Journal of Financial Counseling and Planning, 20(206), 15-24.

Nayak, S. (2013). Determinants and Pattern of Saving Behaviour in Rural Households of Western Odisha, Thesis Submitted to Department of Humanities and Social Sciences, NIT Rourkela, (May), 90.

OECD INFE. (2011). Measuring Financial Literacy: Core Questionnaire, Measuring Financial Literacy: Questionnaire and Guidance Notes for Conducting an Internationally Comparable Survey of Financial Literacy, 31.

Perry, V. G., \& Morris, M. D. (2005), Who is in Control? The Role of Self-perception, Knowledge and Income in Explaining Consumer Financial Behaviour, The Journal of Consumer Affairs, 39(2), 299313.

Robb, C. A., \& Sharpe, D. L. (2009), Effect of Personal Financial Knowledge on College Students' Credit Card Behaviour, Journal of Financial Counseling and Planning, 20(1), 25-43.

Robb, C. A., \& Woodyard, A. S. (2011), Financial Knowledge and Best Practice Behaviour, Journal of Financial Counseling and Planning, (205), 60-70. https://doi.org/10.1177/1090198112463021. 
Sayinzoga, A., Bulte, E. H., \& Lensink, R. (2016), Financial Literacy and Financial Behaviour: Experimental Evidence from Rural Rwanda. Economic Journal, 126(594), 1571-1599. https://doi. org/10.1111/ecoj.12217.

Semmler, L. V. (2016), Financial Decision Making in Rural India: Poverty, Financial Literacy and Investment Decisions, Retrieved 6 15, 2018 from https://ediss.uni-goettingen.de/handle/11858/001735-0000-0028-881b-1.

Sikkim, G. of. (2013). Sikkim : A Statistical Journal 2013, Retrieved August 15, 2017, from https:// www.sikkim.gov.in/stateportal/UsefulLinks/Sikkim A Statistical Journal 2013 (DRAFT).pdf.

Stenning, A., Smith, A., Rochovska, A., \& Swiatek, D. (2010), Credit, Debt and Everyday Financial Practices: Low-income Households in Two Postsocialist Cities, Economic Geography, 86(2), 119145, https://doi.org/10.1111/j.1944-8287.2009.01066.x.

Tang, N., \& Baker, A. (2016), Self-esteem, Financial Knowledge and Financial Behaviour, Journal of Economic Psychology, 54, 164-176. https://doi.org/10.1016/j.joep.2016.04.005.

Xiao, J. J., Ahn, S. Y., Serido, J., \& Shim, S. (2014), Earlier Financial Literacy and Later Financial Behaviour of College Students, International Journal of Consumer Studies, 38(6), 593-601. https:// doi.org/10.1111/ijcs.12122.

Xu, L., \& Zia, B. (2012), Financial Literacy Around the World: An Overview of the Evidence with Practical Suggestions for the Way Forward, Retrieved 6 16, 2018, from http://elibrary.worldbank. org/doi/pdf/10.1596/1813-9450-6107. 